\title{
Research Paper: Persian Adaptation of Enhanced Milieu Teaching for Iranian Children With Expressive Language Delay
}

Yalda Kazemi $^{{ }^{* *}}$ (D), Fatemeh Mohebbinejad ${ }^{1}$ (I)

1. Child Language Research Cluster, Department of Speech Therapy, School of Rehabilitation Sciences, Isfahan University of Medical Sciences, Isfahan, Iran.

\begin{tabular}{|c|c|}
\hline $\begin{array}{l}\text { Use your device to scan } \\
\text { and read the article online }\end{array}$ & \\
\hline 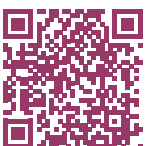 & $\begin{array}{l}\text { Cltation: Kazemi Y, Mohebbinejad F. Persian Adaptation of Enhanced Milieu Teaching for Iranian Children With Expressive } \\
\text { Language Delay Iranian Rehabilitation Journal. 2020; 18(1):99-112. http://dx.doi.org/10.32598/irj.18.1.930.1 } \\
\text { dol' http://dx.doi.org/10.32598/irj.18.1.930.1 }\end{array}$ \\
\hline
\end{tabular}

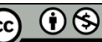

Article info:

Received: 21 Jul 2019

Accepted: 22 Oct 2019/10/

Available Online: 01 Mar 2020

\section{Keywords:}

Language delay, Early intervention, Parenthood education, Milieu therapy

\section{ABSTRACT}

Objectives: This study aimed at adapting and examining the applicability of the Teach-ModelCoach-Review model of the Enhanced Milieu Teaching (EMT) approach for improving Iranian mothers' language strategies while interacting with their toddlers with expressive language delay.

Methods: In a single-subject multiple-baseline across-behavior study, the mothers of 3 toddlers with expressive language delay attended a series of intervention sessions to be taught how to modify their interaction strategies/behaviors, including noticing and responding, turntaking, and expanding. Their behaviors were video-recorded, and the percentages of mother's behaviors were calculated. Visual analysis and an Improvement Rate Difference (IRD) metric were provided to document the mothers' progress. Fidelity was checked, using a checklist of items taught by the clinician, as well as a quality check of the sessions.

Results: Mothers indicated the improved levels of strategy usage after receiving EMT and maintained their skills at criterion levels after the termination of the intervention. IRD for notice-respond, turn-taking, and expanding was $0.88,0.91$, and 0.88 for FA's mother, respectively. IRD was 0.92 and 1 for AM's mother. The two strategies of notice-response and turn-taking showed IRDs of 1 and 0.66 for KA's mother.

Discussion: Iranian speech therapists employ a Persian-adapted edition of the Teach-ModelCoach-Review model of EMT with confidence to follow the improvement of parents' strategies usage within an early intervention course of management of child language delay. The model provides a systematic education of parents to address the communication needs of their children.

\section{* Corresponding Author:}

Yalda Kazemi, PhD.

Address: Child Language Research Cluster, Department of Speech Therapy, School of Rehabilitation Sciences, Isfahan University of Medical Sciences, Isfahan, Iran.

Tel: +98 (913) 1281885

E-mail: kazemi@rehab.mui.ac.ir 


\section{Highlights}

- Enhanced milieu teaching in the form of Teach-Model-Coach-Review has been adapted to Persian.

- Persian-adapted Teach-Model-Coach-Review improves Iranian mothers’ language strategies.

- The Teach-Model-Coach-Review model provides a systematic way of parents' education of language strategies.

\section{Plain Language Summary}

Parents of children with communication problems cannot sometimes use language strategies efficiently while interacting with their children. So, it may affect the children's communication skills in the natural environment. A model called Teach-Model-Coach-Review that follows the principles of milieu teaching makes the parents' education more systematic and comprehensive. The current study adopted this model to Iranian society to provide Iranian speech therapists with the first systematic protocol for parents, whose children's expressive language is delayed. The language strategies that were targeted in this study included noticing and responding, turn-taking, and expanding.Four children with their mothers attended a series of speech therapy sessions. We asked the mothers to look at different strategies modeled by the clinician. Then, they were asked to react to each strategy, and they were coached during performing strategies with their children. All steps were video-recorded and, finally, the clinician reviewed all steps with the mother by watching the recordings and provided feedback to the mothers. Iranian mothers learned and used all language strategies with high levels of accuracy and their children showed improvements in vocabulary targets. Hence, it is suggested that Iranian speech therapists implement this model in clinical settings to make the parents' education more systematic and effective.

\section{Introduction}

arents are children's first language part-

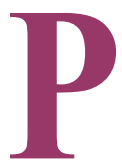
ners and have significant roles in children's language development. Communicative methods used by parents of children with suspected language impairment might be insufficient, and even difficult, for children's communicative development [1]. Teaching parents to modify interaction techniques and language inputs is an important factor in early intervention for children with language impairment [2]. Parents of children with language problems represent lower scores in interaction aspects, such as how and how much they respond to the child's communication and interactions, as well as the quantity and quality of their linguistic inputs and how they apply to learn strategies to support their child, compared to parents of children with normal language development.

Also, both groups of children's rate of communication, joint attention, clarity of communicative intentions, intelligibility, and responsiveness to language are affected by aspects of parent-child interactions. Therefore, one of the important components of early intervention is to train parents on how to modify linguistic ways of interacting with their children with language impairments [2]. Early intervention is critical for improving the behavioral, communicative, and interaction skills of young children with different difficulties ie intellectual disabilities (e.g., Down syndrome), autism spectrum disorders, and delay in expressive or receptive language; parents are the most important components of early intervention.

These types of intervention focus on family education and preparation in the form of family-centered approaches. It means that the educator focuses on enhancing the quality of parent-child interactions according to daily activities that embed the early intervention within the learning in natural environments $[3,4]$. Children's behavior, communication, and language skills, as well as parents' interaction strategies, have been targeted in several early intervention programs such as Parent-Child Interaction Therapy [5], Early Start Denver Model [6], Hanen's More than Words [7], Parent-Implemented Communication Strategies [4], and Language and Play Everyday [3].

In a randomized control trial, Bagner and Eyberg examined the effect of parent-child interaction therapy on the disruptive behaviors of 30 children with intellectual disabilities aged 3 to 6 years. The results showed that the treatment group had a more positive interaction with their children and less destructive behaviors at home compared to the waiting group. Also, their children were more compliant after the treatment [5]. Another intensive 
early intervention program educated families of children aged 12 to 36 months with autism. By focusing on the family and the child, it introduced the child to interactive social interaction, increased social presence, and expanded play activities into shared daily activities. The results showed that children progressed in spontaneous vocalization, imitation behaviors, and initiation. Moreover, the overall participation in parents' interactions improved. Parents maintained the use of approach techniques within the follow-up period of 3 months after the treatment [6].

In a randomized control trial, Carter et al. performed the Hanen program on 62 children, 51 boys and 11 girls with the age between 18 and 22 months with autism spectrum disorders and their parents. The child's relationship and parents' responses were assessed at each time point. The children's interest in objects was assessed for the first time. The results showed that intervention facilitated the communication of children, who were less interested in objects [7]. The parent-implemented communication strategies program of Stoner et al. has 5 sets of goals, including sharing views and creating short- and long-term goals, teaching parenting intervention strategies, setting meeting goals and implementing intervention strategies, parent observation with giving feedback and progress evaluation, monitoring progress, and setting new goals.

The results of this project were positive for both parents and children and socially well recognized by parents with or without children with disabilities, special education teachers, and speech and language pathologists [4]. Moor et al. included 8 families of infants with verbal communication delays at the age group of 22 to 36 months in the language and play everyday program. It is a communitybased and educational model aimed at enhancing parents' ability to improve their children's communication skills by focusing on training parents to apply natural language augmentation strategies during daily activities. Social validity showed that parents were satisfied with the trends, goals, and outcomes of the study and, more importantly, that children's speech-language skills improved [3].

Enhanced Milieu Teaching (EMT) is one of the most studied programs that engage parents and caregivers in the early intervention of communication problems [8]. EMT is derived from milieu teaching, as classified by Fey's intervention approaches. He has outlined 3 basic approaches to intervention, including the clinician-directed approach, the child-centered approach, and hybrid approach; milieu teaching is one of 3 components of hybrid approaches to facilitate communication in young children $[9,10]$.
EMT focuses on the child's interests, modeling language, and managing her/his environment to induce the child to initiate interaction [11]. Its 7 components include play and engage, notice-respond, balanced turntaking, mirroring and mapping, modeling and expanding communication, environmental arrangement strategies, and EMT-promoting strategies [1]. In play and engage component, play solutions and fun activities are taught to parent with the child during everyday situations and activities. They are educated to find appropriate compatible with the child's level of development.

Parents are taught to pay attention to any child's communication efforts to notice and respond to component and have face-to-face communication and describe all the child's activities. In the turn-taking component, parents learn to balance communication shifts. It means they should wait for the child to communicate and, then, respond once. In mirroring and mapping component, parents imitate the child's behavior and, then, model the appropriate word for that activity. Through the expanding component, parents learn to extend gestures to words, single words to two-word phrases and phrase to sentences and, then, model them to the child. The environmental arrangement component includes activities without verbal stimulation that make the child start the communication. In prompting strategies, parents are trained to prompt children directly to communicate, such as answering open-end questions.

More than 50 studies have investigated the usefulness of EMT for improving communication in both normal and affected children [1]. In a meta-analysis of 18 studies on the effectiveness of Parent-Implemented Language Intervention (PILI), including all types of PILI on 18- to 60-monthold children with primary and secondary language impairments, when considering children's outcomes, the lowest and largest effect sizes were reported for receptive language (Hedges' $\mathrm{g}=0.35$ ) and expressive morphosyntax (Hedges' $\mathrm{g}=0.82$ ), respectively; the latter was the most affected outcome. Parents of children, who received PILI, reported that their children significantly expressed, on average, 52 more words than the control groups [2]

The children's outcomes were lately backed up by a randomized controlled trial, in which 16 children with language impairment received PILI in the form of EMT called Teach-Model-Coach-Review (TMCR) feedback cycle. The children were matched with 18 peers for their clinical condition and 28 normal peers as age-control groups. The results signified that the expressive vocabulary of children with language impairments, who 
received EMT, was significantly higher than their peers in both control groups [2].

It is contrary to a similar study by Law et al., in which the parents were taught Hanen's Parent Program in a group training format [12]. The former study asserted that it was impossible to conclude which part of the EMT training program was responsible for the significant disparity between the two studies because of several intrinsic differences between two programs, such as "levels of parental strategy use, individualized training, parent training procedures, selection of individualized child language targets, inclusion of time delay, and prompting procedures" [13].

Although there is a clear positive impact of PILI on the outcomes of children with language delay, only a few studies have directly measured parents' outcomes in terms of the use of intervention strategies that document parents' training methods $[2,14]$. According to the sole meta-analysis on the effectiveness of PILI, only 10 out of 18 eligible studies looked into parents' outcomes by measuring strategies that parents specifically use to support children's language. Parents' responsiveness, modeling language, and the rate of communication were positively affected by the use of PILI by children's parents compared to control groups and the effect sizes ranged between 0.26 and 0.76 [2].

Roberts and Kaiser suggested that conducting studies specifically target training parents as the main goal of the intervention and how accurate they apply the language learning strategies with their children [2]. The effects of using EMT strategies followed by training parents were examined in some other studies. Kaiser and Roberts indicated that parents in the "parent+therapist group" applied more EMT strategies at home compared with untrained parents in the "therapist only group" and maintained their achievement during the time [15]. The positive effects of training EMT on parents were observed in Single-subject Design (SSD) studies. Parents of 6 preschool children with autism or pervasive developmental disabilities and 4 preschool children with developmental delays maintained their use of the newly-learned interaction strategies in the clinic and at home 6 months after the termination of an SSD study [16].

Similarly, 4 parents of children with developmental delays represented an improvement in using strategies in the clinic and generalized them to the home [17]. The effectiveness of the TMCR approach was examined in two recent SSD studies with children with expressive language problems and children with Down syndrome.
Roberts et al. taught 4 caregivers to use 4 EMT strategies with their 24- to 42-month-old children with expressive language problems. The caregivers increased the usage of EMT strategy and all children improved their communication targets within 24 individualized sessions [14]. Also, parents of 4 children with Down syndrome increased their use of 5 EMT language strategies after intervention with a high level of fidelity [18].

Concerning the use of parent-implemented interventions outside the North Atlantic plus Australia region, several studies were found in Iran, the country of the current study. The Sensory Kids Impaired-Home Intervention Parent-Infant Program, which was developed for under-3-year-old hearing-impaired Iranian children, indicated that the children's auditory skills developed at a higher rate after using the Sensory Kids Impaired-Home Intervention [19]. In another study, implementing the Lovaas approach at home settings improved the developmental outcome of 30 Iranian 8-year-old children with autism in terms of communicative interaction, speech, and language abilities and play and behavior levels [20].

Our study attempted to meet Roberts and Kaiser's concerns on measuring parents' improvements on language learning strategies, using a direct training approach, as well as systematic recording of parents' learned language intervention strategies individually [2]. This study aimed at evaluating the parents' outcomes of teaching each strategy of EMT in the form of the TMCR approach to Iranian parents, whose toddlers were delayed in language acquisition. The target outcomes were the mothers' rate of using communicative strategies/behaviors with their children, whose expressive language was delayed. The side gains of this study were to provide Iranian speech-language therapists with the first adapted EMT language intervention in Iran. Three strategies of notice-respond, turn-taking, and expanding communication were investigated. The TMCR feedback cycle provides a structured teaching flow of these strategies to the parents, which affects their use of strategies $[1,14]$.

Foundation of the TMCR approach was described by Trivette et al. by introducing 6 training methods for adults in a meta-analysis. The results showed that learning strategies affect the adults' knowledge, skills, attitudes, and self-efficacy and the largest effect was observed when several strategies are applied simultaneously [21]. So, Kaiser and Roberts implemented multiple adult learning strategies into the TMCR model of parent training. TMCR divides treatment sessions into 4 parts. In the teach part, parents learn specific targets of EMT strategies. In the model part, the therapist mod- 
els the target strategy with the child and shows parents how to implement a strategy. In the practice part, parents use the target strategy across interaction with the child and the therapist provides appropriate feedback. At the end of the session, in the review part, the therapist and parent discuss the session and summarize their impressions of strategies [1].

\section{Methods}

The current study followed a single-subject multiplebaseline across-behaviors design, which included baseline, intervention, and maintenance phases. As an introduction to intervention studies, SSDs help to extensively assess individual PILI programs. This research design looks at each subject uniquely, which can be easily adapted to the flexible nature of the EMT approach, in which each child and her parents are provided with individual intervention plans that are compatible with the parents' skills, preferences, and concerns for their child's language needs in the daily communication [1].

The participants included 3 mothers and their children (KA, AM, and FA) living in Isfahan, Iran. The inclusion criteria included: a. age between 24 and 30 months; b. normal overall development according to the Persian standardized Ages and Stages Questionnaire-2 [22] with a lower score in communication domain; c. normal hearing according to auditory brainstem response infant screening; d. normal health and neurological conditions as reported by parents, recorded in the child's medical profile, and confirmed by a child neurologist; e. an expressive lexicon lower than 50 words without considerable combination of words according to the parents' reports, using Persian MacArthur-Bates Communicative
Development Inventory (MCDI-Persian) [23]; f. being monolingual Farsi speakers. They were recruited from a waiting list of a university clinic after they signed the informed consent. The research was conducted in full accordance with the World Medical Association Declaration of Helsinki and the additional requirements. Table 1 presents the participants' demographic data.

\section{Procedure}

Three mothers were invited to attend a group meeting before starting the program to be informed about the study's aims and process. It was explained that the intervention included 2 individual sessions per week with a length of 40 minutes each in a speech therapy clinic room. Mothers were asked to choose the preferable words as stimulants to be targeted in treatment procedures because a core component of EMT is considering the child's preferences [1]. Also, they were explained that all sessions were video-recorded with full security, meaning that the recordings would not be distributed or broadcasted in any form and with any intention without their permission. Parents and their children were free to choose to play on the floor, at a children's table, or inside a playing net. Different toys were provided to deliver the strategies, including dollhouse with dolls, colorful blocks, puppets, toy cars, pictures of animals and fruits, balls, and simple puzzles.

The therapist was a second-year postgraduate student with 3 years of experience in the field of child language therapy. The first author supervised the therapist's work by watching the videos, providing feedback in-session or offline, and checking the performance of each component so that the fidelity of her work is obtained.

Table 1. Participants' demographic characteristics

\begin{tabular}{|c|c|c|c|}
\hline Participants' Characteristics & FA & AM & KA \\
\hline Age (months) & 27 & 27 & 23 \\
\hline Gender & Female & Male & Male \\
\hline Number of siblings & None & None & None \\
\hline Hearing impairment & - & - & - \\
\hline Neurological disorder & - & - & - \\
\hline Communication score of ASQ (Local norm mean \pm SD) & $42(54.9 \pm 11.3)$ & $40(54.69 \pm 11.3)$ & $30(54.2 \pm 11)$ \\
\hline Expressive vocabulary (MCDI-Persian) & 38 & 10 & 13 \\
\hline Number of word combinations & 4 & 2 & 0 \\
\hline
\end{tabular}




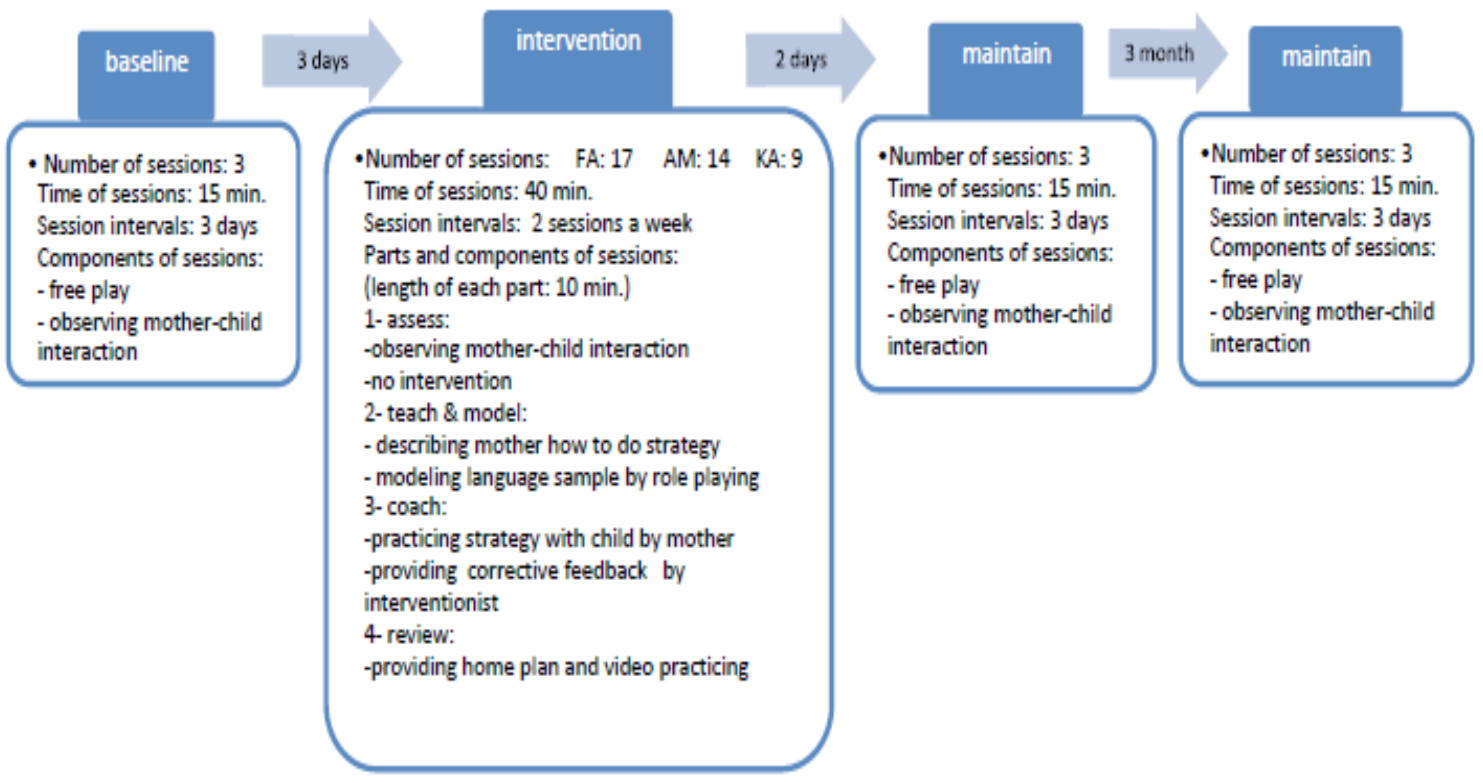

Figure 1. The process of the study

Iranian Rehabilitation \ournal

Program progress included 3 phases of baseline, intervention, and maintenance sessions. The TMCR model of EMT, as an independent variable, was performed in the intervention phase. Figure 1 summarizes 3 phases.

The used strategies of EMT (notice-response, balanced turn-taking, and expanding) were considered dependent variables or behaviors (Please refer to the appendix for examples). They were assessed and scored based on the observations of the mothers' usage of communicative strategies/behaviors when interacting with their children during the 3 baselines 15-minute free play sessions with 3-day intervals in a play setting without previous intervention. While the first target behavior, notice-response, was taught at the beginning of the intervention phase, baseline data collection of two other strategies continued.

The criterion level for notice-response was set at $80 \%$ (ie when the behavior consisted of $80 \%$ of the mother's total correct usage of learned strategy, the next strategy/behavior could be taught). Turn-taking was taught with a criterion level of $75 \%$ correct use, and the criterion level of expansion was set at $50 \%$ correct use [1]. Two maintenance sessions, with no teaching provided, were conducted to encourage mothers by having them watched and compared their progress in sample videos of the baseline and intervention phases. One more maintenance session was arranged for 3 months after the intervention phase.
The total percentage of accomplished strategies/behaviors was also collected at the end. The therapist counted the number of correct usages of each targeted strategy/behavior in the first 10 minutes of each session and divided it by the total use of strategies to calculate the percentage of correct usage of them (Figures 2-4). The independent variable was the TMCR model of EMT and the dependent variables included the mothers' usage of strategies in percentage. The data were analyzed, using the Improvement Rate Difference (IRD) metric to observe the difference between the two conditions of nonintervention and intervention [24]. IRD is the numerical difference between improvement rates of the treatment phase and baseline phase [25]. IRDs between 0.50 and 0.70 are moderate-sized effects and IRDs of more than 0.70 and 0.75 are considered large and very large [25]. The IRD is reported for each child's mother 's use of 3 strategies/behaviors. Also, level parameters (red horizontal lines) in figures show a visual analysis of each strategy.

\section{Results}

Considering that the study employed an across-behavior design, Figures 2-4 demonstrate the comparison across each other's behaviors. The figures include 3 graphs, each showing the 3 strategies/behaviors used by mothers. Two vertical lines divide each graph into 3 panels of baseline, intervention, and maintenance. The vertical axis represents the percentage of strategy/behavior used by mothers, and the horizontal axis comprises the number of sessions. 


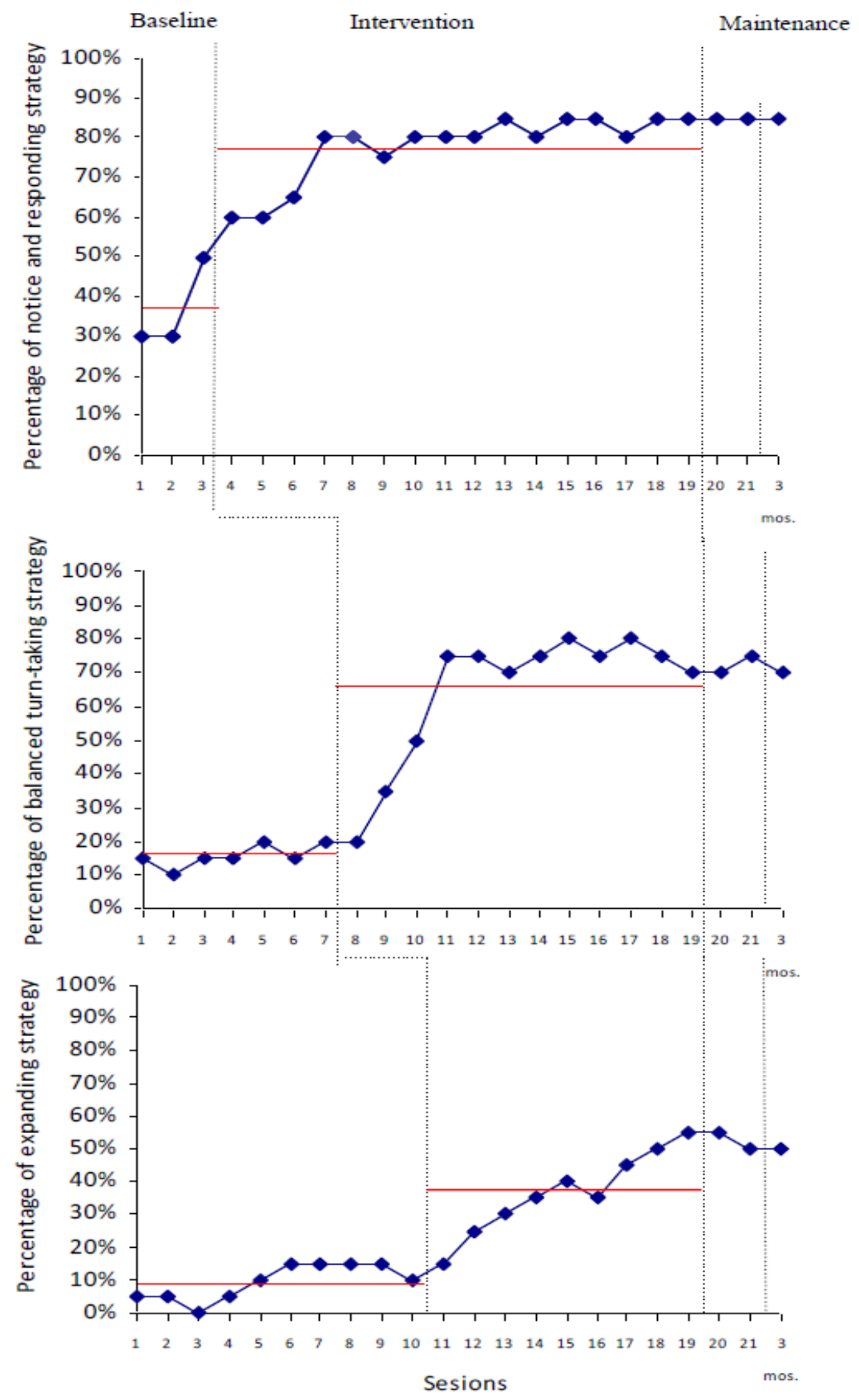

Figure 2. The use of components of EMT by FA's mother

Iranian Rehabilitation \ourna

FA's mother's use of strategies

As shown in Figure 2, the level of changes in FA's mother's use of 3 strategies in the intervention phase shows higher usage compared to the baseline phase. All points of the notice-respond strategy show higher levels than the baseline, meaning that the teaching strategy had an immediate effect on improving mother's learning of this strategy since the lowest point of the intervention phase is still higher than the highest point of the baseline. Only the first point of turn-taking and expanding strate- gies overlap with the baseline points, which can be attributed to her attempt at becoming familiarized with the strategies. If the intervention continued for several more sessions, the expanding strategy would have exceeded $50 \%$ of usage.

IRD for notice-respond, turn-taking, and expanding was $0.88,0.91$, and 0.88 , respectively, which is high enough [25] to assume that the TMCR model of EMT is effective in improving FA's mother's communicative strategies. 

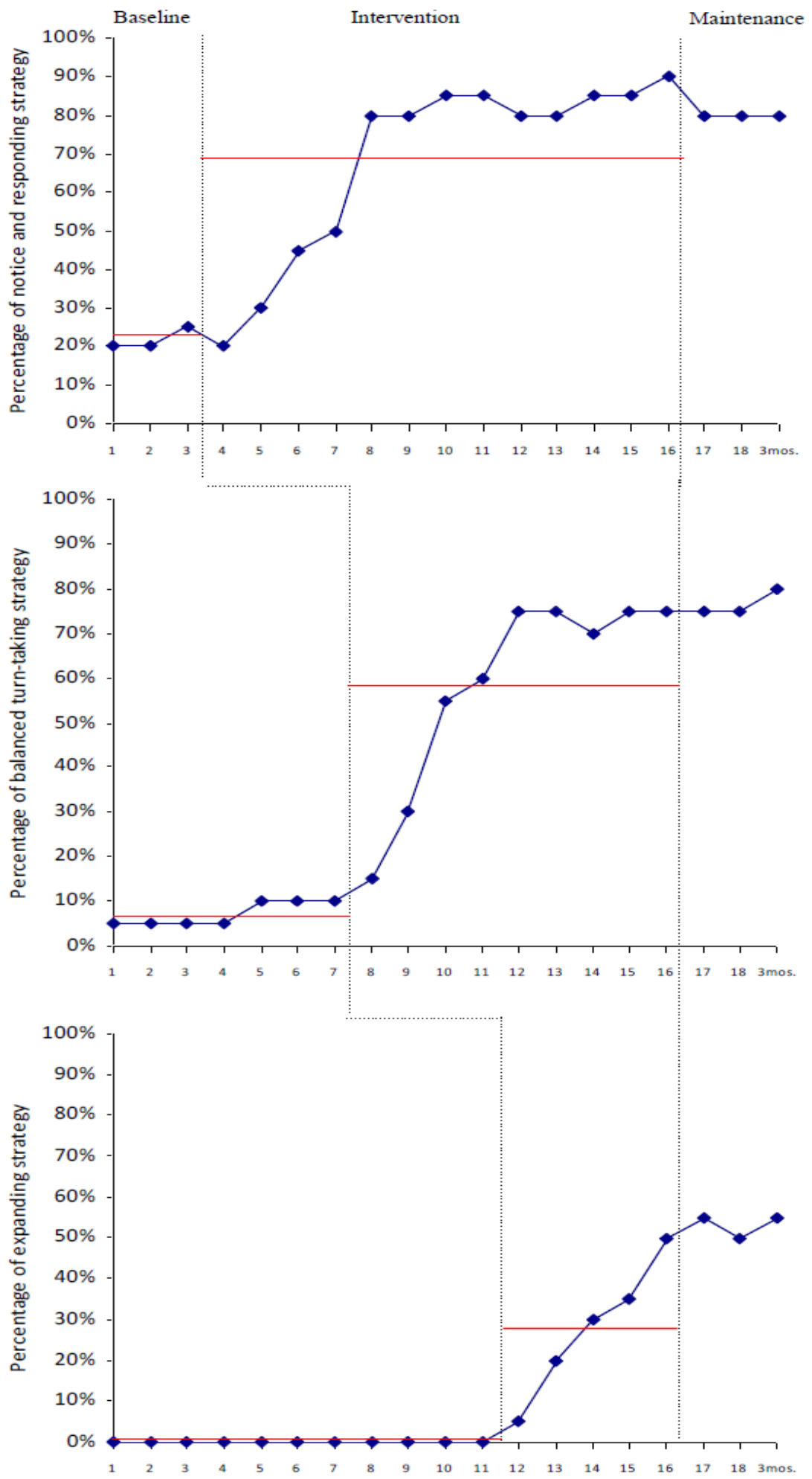

sessions

Figure 3. The use of components of EMT by AM's mother

Пranian Rehabilitation】ournal

AM's mother's use of strategies

AM's mother shows obvious progress in applying all strategies at the first sessions and the trend of treatment compared to the baseline phase. As shown in Figure 3, she met the criteria within 6 sessions after the intervention for notice and response and 5 sessions after the intervention for the other two strategies, which also stayed at the criterion level during the 


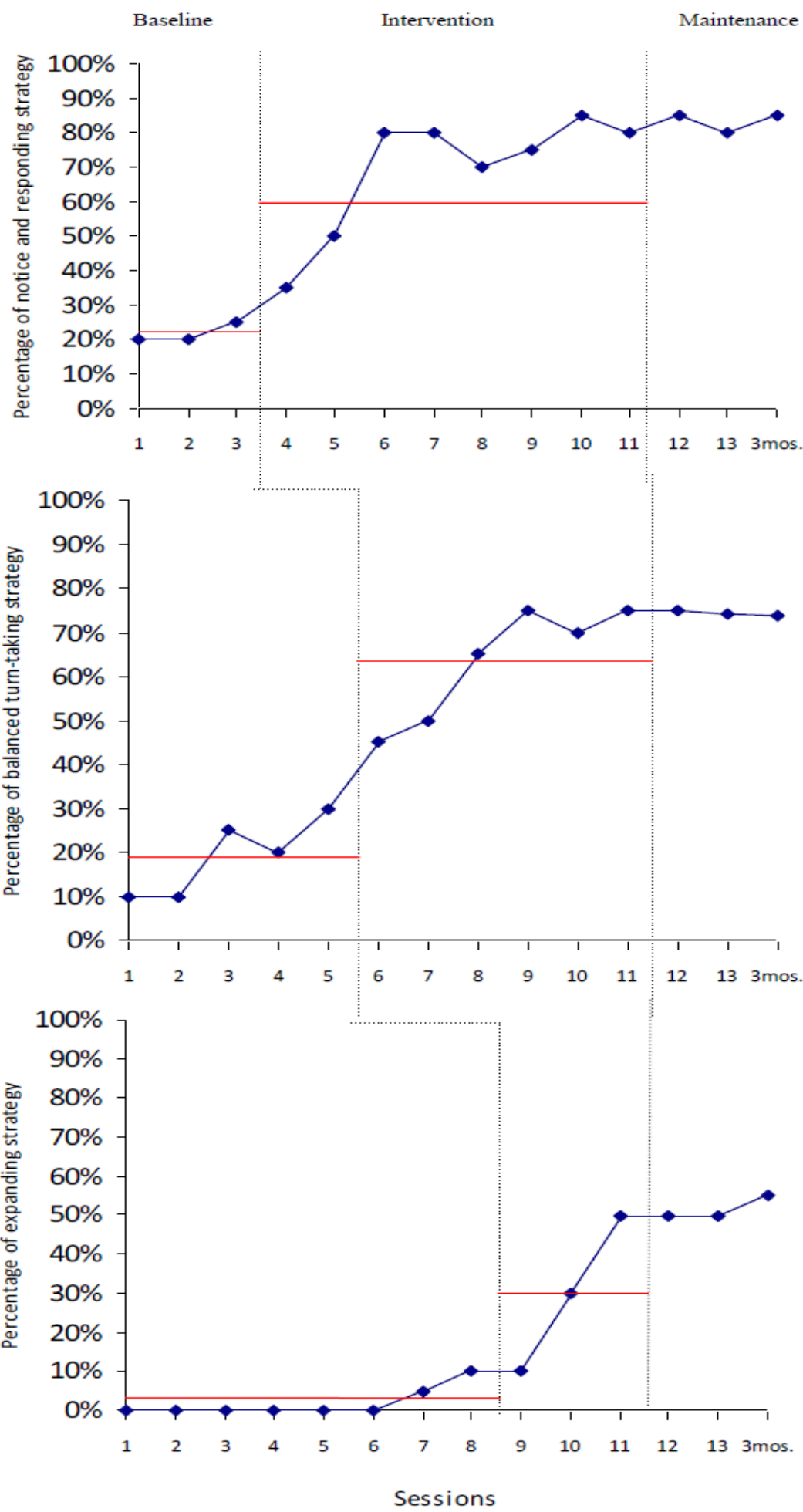

Figure 4. The use of components of EMT by KA's mother

Iranian Rehabilitation Dournal

maintenance phase. The expanding strategy started meeting the criterion level in the last session of the intervention phase and stayed there during the maintenance phase. If the intervention had continued, the mother would have met the criterion level of $50 \%$. Considering the large IRD, which is between
0.92 and 1, it can be assumed that the TMCR model of EMT is effective in improving AM's mother's interaction strategies. 


\section{KA's mother's use of strategies}

KA's mother did not attend all agreed sessions. However, the diagrams of her use of the first two strategies indicate a gentle increase in the levels and trends of applying the strategies while interacting with her child (Figure 3). Both strategies reached the criterion levels within 3 sessions and stayed there during the maintenance phase. Two points, however, have dropped to $5 \%$ below the criterion level for notice and respond, and one point dropped in balanced turn-taking. This can be attributed to her irregular attendance in the intervention phase. This variability can be overlooked by her ability to stay at criterion levels in the maintenance phase, though. The expanding strategy, however, shows a dramatic increase within 2 sessions, which continued to the maintenance phase, climbing beyond criterion, which secures its rise in case of regular attendance and uninterrupted intervention. The two strategies of notice-response and turn-taking show IRDs of 1 and 0.66 for expanding, documenting a full effect of the TMCR model of EMT on KA's mother's use of communicative strategies.

In general, although the mean percentages of behaviors did not meet the criterion levels, all mothers improved the targeted interaction behaviors supported by most IRDs rest in high levels. All strategies were maintained at or beyond criterion levels for all participants immediately after the intervention phase and 3 months later. Although the aims of the study do not include children's outcomes, their language improvement was prominent to report such briefly. Expressive single words increased to 173,125 , and 310 for FA, AM, and KA 3 months after the intervention according to MCDI-Persian. Their word combinations also increased to 55, 16, and 36 for FA, $\mathrm{AM}$, and KA 3 months after the intervention [26].

\section{Discussion}

This study aimed at evaluating the effects of using milieu teaching in the form of TMCR to improve Iranian mothers' use of communicative strategies with their children with expressive language delays. The results confirmed that the approach established significant changes in mothers' behaviors during intervention sessions and by maintaining the use of strategies immediately and after 3 months of intervention. The notice-response strategy was the most easily learned behavior, and it was maintained at high levels of criterion. The expanding strategy was the most difficult one to practice and maintain.
Although irregular attendance and a mother's early satisfaction with her child's progress can be two possible reasons for the difficulty with practicing and maintaining the expanding strategy, it may also be a result of the child's one-word expressive language level. Because the participating children were delayed in developing expressive words, they had communicated, using only a few single words with no combination within a long period. Additionally, all 3 children were children without siblings, and the mothers did not have enough experience with encouraging their children's language development; so, they were less aware of using the expanding strategy to lengthen the child's utterances.

The results of this study are similar to several recent studies, which evaluated the effects of the TMCR approach on caregivers' use of EMT strategies and children's expressive language skills, in which the caregivers enhanced their use of 4 strategies, generalizing and maintaining them at home after being taught the strategies [14]. Although because of the fund limitations of the present study, it included neither a generalization phase at home nor detailed children's outcomes, significant changes occurred in the mothers' behaviors, which were maintained after 3 months.

It is noticeable that the strategies were taught only in a play setting in a clinic room, but we informally observed mothers generalizing while interacting with their children out of the play setting. Thus, it is expected that the mothers would improve their communicative strategies at other settings of interaction, such as book reading and daily routine conversation, which are introduced to the intervention phase. Besides, the expanding strategy requires more time to be established in mothers' communicative behaviors. Further validation of the study may be gained by continuing and following the generalization of strategies used by mothers at home during later months.

This result is also similar to the results of a recent study that compared the effects of EMT strategies for preschool intellectual disabled children by their parents, who participated in parents with therapists group, and parents, who did not receive training (in therapist only group). Parents in the former group showed more effective usage of strategies rather than the parents in the other group with evidence of longer maintenance of use over time [15]. Such effectiveness was observed at the onset of the intervention phase in the current study when the mother had modified her strategies by asking the therapist some questions to correct her mistakes when she was at home without direct guidance. 
The current result is alike to the results of a study, which examined applying EMT by parents in using naturalistic language in interaction with their preschool children with autism or pervasive developmental disabilities. Along with both studies, parents learned to communicate with children through daily requisite language. Parents of children with pervasive developmental disabilities kept going on their use of trained methods 6 months after the intervention, but their progress was at a lower level of the intervention phase at the clinic. However, the parents of the present study maintained their improvement levels after 3 months and did not descend from the targeted criteria [16].

Positive effects of learning EMT strategies by parents in interaction with children in the current study are similar to the results of a study that evaluated the results of teaching EMT strategies to 4 parents with delayed developmental children at preschool age. They could learn the implementation of strategies in the clinic and generalized them at home despite parents in the present study [17].

In general, this study confirms that the conceptual framework of parents' training to target their children's language skills would benefit Iranian families, as well. The different parts of the model provide enough time and a chance for both clinicians and parents to set linguistic and communicative goals. Parents of children with language delays are weak in providing linguistically- and interactional-rich environment for their children [2]. If this happens within not only early years of life but also early months or days after receiving the diagnostic label, the child, the parents, and the clinician would benefit from early intervention. The results of the children, which were published previously, showed that the children's outcomes, including name expressive vocabulary, verb expressive vocabulary, and word combinations had been improved with a range of IRDs between 0.60 and 1 , which is moderate to very large [26].

\section{Limitations and Suggestions}

It is suggested that the results of this study should be further validated by group studies that empower the effect of the TMCR approach with large sample sizes, randomization, and controlling biases. It is suggested that future studies consider the detailed and direct evaluation of the procedures of parents' training and learning. Also, systematic measurement of parents' use of intervention strategies, as an outcome of parent training procedures, is necessary because only when measures of parent training and parent implementation are included in studies, it will become possible to examine particular parental characteristics (e.g., education or buy-in to the intervention) that may influence the parental use of language intervention strategies and child language outcomes.

Other strategies of the model would also be worth investigating with Iranian children with different kinds of developmental speech and language disorders. It is also suggested to scrutinize the impact of this model on improving children's outcomes, such as vocabulary growth, utterance length, and communicative intentions with more details.

\section{Conclusions}

Although the results should be considered with caution owing to the study design, Iranian speech-language therapists can implement the TMCR model in clinical settings to inspect the improvement of the communicative behaviors of the mothers, whose children are affected by communication disorders

\section{Ethical Considerations}

\section{Compliance with ethical guidelines}

The ethical approval of the study was issued by the independent Research Ethical Committee of Isfahan University of Medical Sciences by the approval Code of 394008.

\section{Funding}

This study was supported by Research Bureau of Isfahan University of Medical Sciences (Grant number: 394008).

\section{Authors' contributions}

Conceptualization, funding acquisition, resources, and supervision: Yalda Kazemi; Methodology, investigation, writing - original draft, writing, review \& editing: All author.

\section{Conflict of interest}

The author declared no conflict of interest.

\section{Acknowledgments}

We would like to thank Dr. Ann P. Kaiser's comments that greatly assisted with the methodology of the study at the onset. We also thank Prof. Philip Dale with his comments on preparing the outlines of the manuscript. 


\section{References}

[1] Kaiser AP, Roberts MY. Parents as communication partners: An evidence-based strategy for improving parent support for language and communication in everyday setting. Perspectives on Language Learning and Education. 2013; 20(3):96111. [DOI:10.1044/lle20.3.96]

[2] Roberts MY, Kaiser AP. The effectiveness of parent-implemented language interventions: A meta-analysis. American Journal of Speech-Language Pathology. 2011; 20(3):180-99. [DOI:10.1044/1058-0360(2011/10-0055)]

[3] Moore H, Barton E, Chironis M. A program for improving toddler communication through parent coaching. Topics in Early Childhood Special Education. 2014; 33(4):212-24. [DOI:10.1177/0271121413497520]

[4] Stoner J, Meadan H, Angell M. A model for coaching parents to implement teaching strategies with their young children with language delay or developmental disabilities. Perspectives on Language Learning and Education. 2013; 20(3):11219. [DOI:10.1044/lle20.3.112]

[5] Bagner DM, Eyberg SM. Parent-child interaction therapy for disruptive behavior in children with mental retardation: A randomized controlled trial. Journal of Clinical Child and Adolescent Psychology. 2007; 36(3):418-29. [DOI:10.1080/15374410701448448] [PMID]

[6] Vismara LA, Rogers SJ. A new focus for parent education: Bridging the gap between diagnosis and intensive early intervention services. Perspectives on Language Learning and Education. 2008; 15(2):60-6. [DOI:10.1044/1le15.2.60]

[7] Carter AS, Messinger DS, Stone WL, Celimli S, Nahmias AS, Yoder P. A randomized controlled trial of Hanen's 'More Than Words' in toddlers with early autism symptoms. Journal of Child Psychology and Psychiatry. 2011; 52(7):741-52. [DOI:10.1111/j.1469-7610.2011.02395.x] [PMID] [PMCID]

[8] Kaiser AP, Gray DB. Enhancing children's communication: Research foundations for intervention. Applied Psycholinguistics. 1995; 16(1):128-36.

[9] Fey M. Language intervention with young children. San Diego, Calif: College-Hill Press; 1986.

[10] Paul R, Norbury C. Language disorders from infancy through adolescence. St. Louis, Missouri: Elsevier Mosby; 2012.

[11] Hancock TB, Kaiser AP. Enhanced Milieu Teaching. In R. McCauley \& M. Fey (Eds). Treatment of language disorders in children. Baltimore: Paul Brookes; 2006.

[12] Law J, Kot A, Barnett G. A comparison of two methods of providing intervention to three year old children with expressive/receptive language impairment. London: England City University London; 1999.

[13] Roberts MY, Kaiser AP. Assessing the effects of a parentimplemented language intervention for children with language impairments using empirical benchmarks: A pilot study. Journal of Speech, Language, and Hearing Research. 2012; 55(6): 1655-70. [DOI:10.1044/1092-4388(2012/11-0236)]
[14] Roberts MY, Kaiser AP, Wolfe CE, Bryant JD, Spidalieri AM. Effects of the teach-model-coach-review instructional approach on caregiver use of language support strategies and children's expressive language skills. Journal of Speech Language Hearing Researches. 2014; 57(5):1851-69. [DOI:10.1044/2014_JSLHR-L-13-0113] [PMID]

[15] Kaiser AP, Roberts MY. Parent-implemented enhanced milieu teaching with preschool children who have intellectual disabilities. Journal of Speech, Language, and Hearing Research. 2013; 56(1):295-309. [DOI:10.1044/1092-4388(2012/11-0231)]

[16] Kaiser AP, Hancock TB, Nietfeld JP. The effects of parent-implemented enhanced milieu teaching on the social communication of children who have autism. Early Education and Development. 2000; 11(4):423-46. [DOI:10.1207/ s15566935eed11044]

[17] Hemmeter ML, Kaiser AP. Enhanced milieu teaching effects of parent-implemented language intervention. Journal of Early Intervention. 1994; 18(3):269-89. [DOI:10.1177/10538 1519401800303]

[18] Wright CA, Kaiser AP. Teaching parents enhanced milieu teaching with words and signs using the teach-model-coachreview model. Topics in Early Childhood Special Education. 2017 ;36(4):192-204. [DOI:10.1177/0271121415621027]

[19] Samadi J, Sedaei M, Rouhbakhsh N, Asad Malayeri S, Faghihzadeh S. [Preparation and evaluation of SKI-HI: A parent-infant auditory training program for under 3- year -old hearing impaired children (Persian)]. Audiology. 2006; 15(1):20-6.

[20] Dalvand H, Dehghan L, Feizy A, Hosseini SA. The effect of home based Lovaas approach on social interaction, speech and language, play and behavior skills, and intensity of autism in young children with Autism (Persian)]. Journal of Modern Rehabilitation.2009; 3(1-2):11-16.

[21] Trivette CM, Dunst CJ, Hamby DW, O'herin CE. Characteristics and consequences of adult learning methods and strategies. Research Brief. 2009; 3(1):1-33.

[22] Sajedi F, Vameghi R, Kraskian Mojembari A, Habibollahi A, Lornejad H, et al. Standardization and validation of the ASQ developmental disorders screening tool in children of Tehran city (Persian)]. Tehran University Medical Journal. 2012; 70(7):436-46.

[23] Kazemi Y, Nematzadeh S, Hajian T, Heidari M, Daneshpajouh T, Mirmoeini A. The validity and reliability coefficient of Persian translated MacArthur-Bates Communicative Development Inventory (Persian)]. Journal of Rehabilitation Sciences \& Research. 2008; 3(4):45-51.

[24] Byiers BJ, Reichle J, Symons FJ. Single-subject experimental design for evidence-based practice. American Journal of Speech-Language Pathology. 2012; 21(4):397-414. [DOI:10.1044/1058-0360(2012/11-0036)]

[25] Parker RI, Vannest KJ, Brown L. The improvement rate difference for single-case research. Exceptional Children. 2009; 75(2):135-50. [DOI:10.1177/001440290907500201]

[26] Kazemi Y, Mohebinejad F. The impact of parent-implemented early intervention on expressive language skills of toddlers with language delay: A single-subject study (Persian)]. Journal of Rehabilitation Sciences \& Research. 2015; 11(5):345-53. 
Appendix 1. The Persian-adapted protocol of Teach-Model-Coach-Review (with examples in Persian)

\begin{tabular}{|c|c|c|c|}
\hline معياز موفقيت والد & 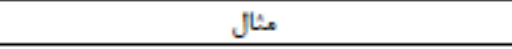 & استراتزي ها & 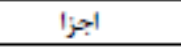 \\
\hline - م درهد لز قرهتباى يبش & - ائتخاب لتو براى كودى & - التئاب السباب بازى هلى جالب و سركرم كسنده & يازي و هشاركت \\
\hline أهده بايد صرف اين جزء تتود & 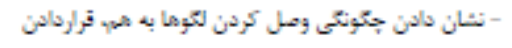 & - ملحق تحدن به كودكى الز طريق بازى فيل با السباب & \\
\hline و والد درحال بازى در بسلح & 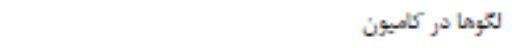 & بازى هائى كه خونت انتخاب كردة استي & \\
\hline كودمى با اسباب بازى ماى & - اداعه بازى با لتوها را به عبده كودى كذاتمتن & - أموزتس فياليت ها و مراحل سطع بازى هدف & \\
\hline هورد مالاقه او بأتسند. & - الكودمبى فعاليت روزهره الكوها را تو كاصيون بذار، لكوها & & \\
\hline & را بريز א. & & \\
\hline - م دروسد از الرتباطلاه كودكى & - وقتى كودكى از لكوها به سعن هاتسين ها حركت هى & - نشستن جهره به جهره با كودك - & توجها و ياسخدهى \\
\hline الز طريق باستخ هاى مادر كه & 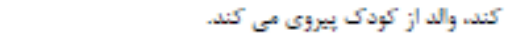 & - يبروى كردن از فعاليت هاى كودك - & \\
\hline وايبسك به قياليت كودك و & - وقتى كودى با صروسك بازى و آواسازى مى كند والد & - واكنش نشان دادن به تعام الرتباطاه كودك & \\
\hline عرتبط با آن ميتد، نيال & وازٔه صربوط به آن را مي كويد. & & \\
\hline قي تَوند & - وقتى كودى به اسباب بلزى درون تخسه اتتاره مى كند & & \\
\hline & 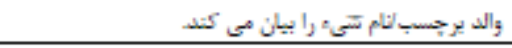 & & \\
\hline VO Vرهد توبت ماى والد. & - كودك نامشهوم حرق مى زتد با اتساره هى كندي والد با & رعايت تحادل در توبت هاى ارتباطلى لزطريق باسخ والد به & رعايت نوبت \\
\hline باستخ به لزتباهلاه با فياليت & وازٔه، علاهت با اتتاره به مدة. باست مى دملد: سبس حسبر & مرتخه كودكى، فتط در يك نوبيت، و منتفلر هاتدن براى & \\
\hline ماى كودكى استع. & مى كند تا توبت كودمى تسود. & نوبت بكلدى كونكى & \\
\hline & 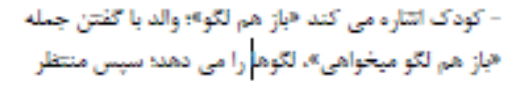 & & \\
\hline & مى ماثد نوبيت كودك تشود. & & \\
\hline VO Vر Vد نوبت هاى والد. & 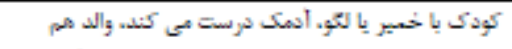 & تقليد قعاليت هاع قير كلاهى كودك و التودهى زباتي & كيى كرن و الكو \\
\hline باسخ به لارتباطلاه يا فيالي= & همين كار را اتجام هى دهد و التودهى هى كند: لأدهك & بيراى اين فياليت & oان \\
\hline ماى كودكى استع. & بسازي. & & \\
\hline - - مل درهد تكغع هاع والد در & - كونك به سيب أتساره هى كند. والد والزه آن را بيان هى & 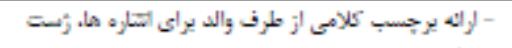 & الغودهى و يسط \\
\hline سطح هدف كودى هيتد. & كند & 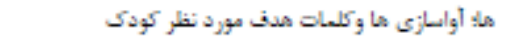 & ارتياط \\
\hline 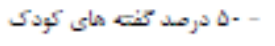 & - كودكى به سيب التاره هى كند و آن را بيان مى كتد، والد & - بسط الرتباط كودك بوسيله اقاقه كرن نشاته ها يا & \\
\hline توسط والد بسط ناده هى & يكى فعل به آن اظـاقه مى كتد و مى كويد " سيب بدهك. & كلعاه & \\
\hline . & & & \\
\hline - م درهد استراترى ماى - & - والد بلدون باز كردن باحت تسير، آن را به كودك مى دمد & - متتطر ماتدن والد براى درخواست كسك لز طرف كودك & ملديريت معيط \\
\hline مديريت دحيط به طلور صحيح & و متسلر درخواست كمك از طرف كودك مي ماند، سبس & 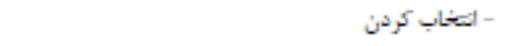 & \\
\hline اجرا مي تَود. & در حال باز كردن باكتع، عباره ماف را التودهى مى كتد & - كودى منتطلر انجام يك قهاليت مانى هميشتى & \\
\hline & 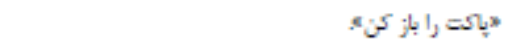 & $=$ & \\
\hline & - والد دو حو التيخاب به كودك مي دماد و منتطلر مي هاتد & - - سرتغ داى غيركلاهى و كلاهى & \\
\hline & 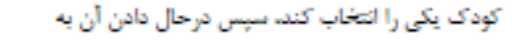 & - فرامع كردن اجزاي ناكافى از طرف والدين & \\
\hline & كودى ، روى مورد التيفاب تسله برجسب كلامى مى كذارد. & & \\
\hline 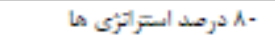 & 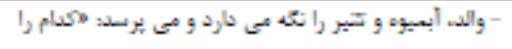 & - بروالاه التها باز & يرانيختن \\
\hline به طور صحيع اجرا هي تَود. & "مى خوائي?" & - - سرالاه النغخابي & \\
\hline & - والد أبعيو، و تشير را تحه مى فارد و مى يرسد: "حتير صى & - براتكيزاننده مستخيم"ايكو" & \\
\hline & خواهى يا آبعيوء؟عه & & \\
\hline & 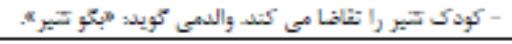 & & \\
\hline
\end{tabular}


This Page Intentionally Left Blank 